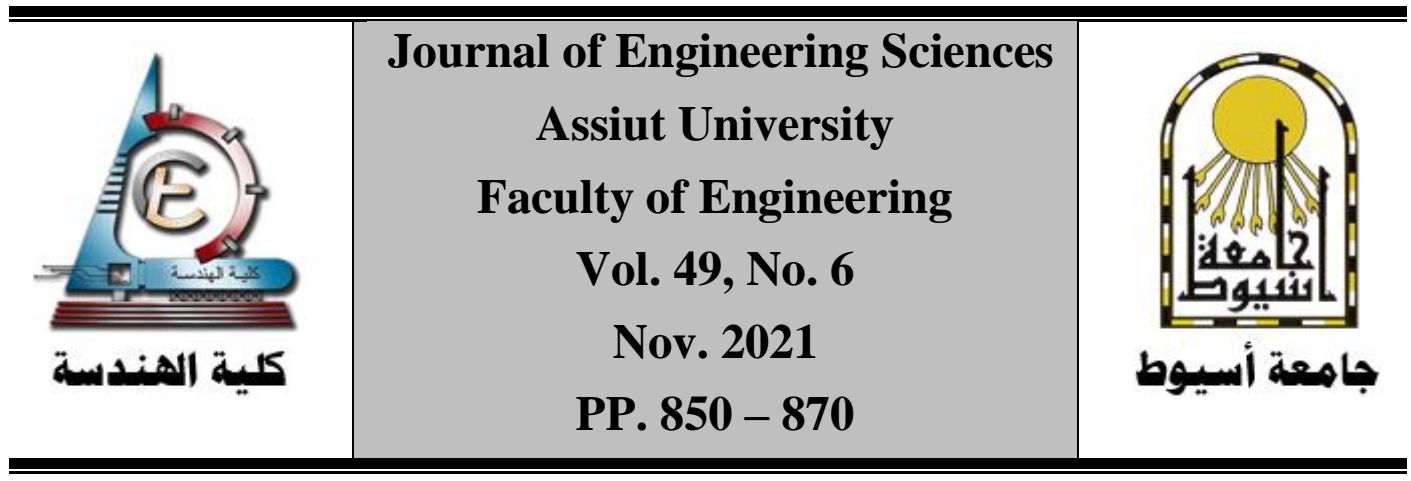

\title{
The role of strategic planning in Spatial Competing between planned and unplanned urban areas of Greater Cairo
}

\section{Said Hassanien Al-Sayed}

\author{
High Institute of Engineering-Thebes Academy for Sciences-Cairo-Egypt
}

siag_gis@yahoo.com

Received 25 February 2021; Revised 23 August 2021; Accepted 05 September 2021

\begin{abstract}
:
The urban uses compete to dominate different areas of the city, The services and commercial uses usually dominate the city centers due to its accessibility, and Industrial uses are also looking for areas with lower value and environmentally suitable, while residential uses distributed near to the services centers and jobs generator areas. Urban areas and uses also compete according to their planning status to become planned or unplanned, the planned residential uses are distributed regularly around services or greens, and usually away from pollution-generating areas such as industry, while the unplanned uses are distributed either around these planned areas or around areas of employment generation, especially trade, services, and industrial activities. This explains the spread of slums and unplanned areas on the outskirts of the city or around industrial areas. The applied urban planning approaches have an effective role on arranging areas and ensuring that they do not turn into slums or informal areas. Egypt applies the comprehensive planning approach from 1950th until 2008 where the strategic planning approach was applied for guiding urban development plan. The research will focus on studying the role of applied planning approaches in Egypt to control areas planning status specially the strategic planning which has not shown a clear positive impact on urban areas even with the participation of civil
\end{abstract}


society and its groups and could not control occupation of land areas by the domestic land use.

Research Aim: To examine the role of applied planning approaches in controlling the state of urban areas in Egypt, and to reinforce the strategic planning tools that contributes to solve the conflict between planned and unplanned areas inside the city, and to create a map that illustrate the interaction between planned and unplanned urban areas inside the city.

Methodology: The descriptive approach will be followed by describing the phenomenon, the variables related to it, and the factors that affect it, and then extracting and generalizing the results, and then use the experimental approach by studding and analyze the urban area of Greater Cairo region, Egypt as case study to apply the approach to formulate theories and axioms according to an ordered system. For the aim of the research an urban map will be drawn that will divide the areas within the study area into three types according to their urban aspects (Planned area- Unplanned areas, Areas under development are undeveloped areas).

Key words: Strategic planning approach, unplanned areas, planed areas, competitive uses

\section{1- Introduction:}

Urban areas are formed to meet residents needs and commensurate with their behavior and characteristics. These urban areas sometimes compete to attract some uses to be concluded in them, some uses compete to occupy lands within urban areas. As a result of this competitions, urban changes are increasing, followed by environmental and social changes. The emergence of urban areas occurs in two approaches: by applying planning approaches and its steps to distribute land uses within a specific area, flowing detailed studies on all branches, and then an urban plans is made for development, the second approach is spontaneous cumulative growth, which is often unplanned, and is carried out by Some members of the community, where they construct residential buildings and some services according to the current needs of each of them without taking into account the full needs of all residents in the area [1].

During the construction phase of the city, a group of supportive activities are attracted around the construction sites, including temporary houses, some services, and street vendors serving main 
workers. With the lack of control over this area, it increased in size and number of occupants and turns into informal area for random activities (as Hagana in Nasr city). Its residents mostly from low social level and variable limited income groups serve the workers in the planned city until the completion of its construction and then serve the city residents (as Imababa near Zamalek) [1]. Most of unplanned areas usually grow near or around planned areas and there are many reasons for its emergence, including: Increase in population growth rates, lack of urban control, the flow of migration from rural to urban areas, increase in the prices of land prepared for construction, including state-owned, increase in the rental value of the housing supply, the desire of parents to live next to their children and relatives, and the limited suitable housing for the lower social groups [1].

\section{2- Definition of planned and unplanned land.}

The Law 119 of 2008 and its executive regulations directed the planners to clarify the areas of different uses that include planned and unplanned areas in addition to the areas of replanning, which are usually informal or deteriorated areas. The characteristics of each kind will be clarified and reinforced with the support of the thinkers and planners in this regard, as well as the planning approaches and tools necessary to preserve the planned areas as the strategic planning approach, and the transformation of the unplanned areas into a planned area, and how to control the undeveloped or under development areas to prevent them to turn into unplanned areas [1].

Planners and thinkers define Planned Area as the area that addressed by any Urban planning approach as city or county planning. Some time it means developed land that have been built [3], they classified the planned areas into Planned Community (PC) [2], Planned Unit Development (PUD). They also define Unplanned areas as the areas that grow without a system or out of low or any urban control, and often by private individuals to provide shelter for them and their families. They often suffer from urban and environmental deterioration, and lack of social services and Utilities including roads and infra-structure networks [4].

The planners classified the unplanned areas to three kinds: pre-urban areas which found at fringe zones around cities, where new urban land 
uses, and activities are being imposed on a rural landscape andlor the area between an urban settlement and their rural hinterland. Such areas are often fast changing, with complex patterns of land use and landscape, they are often far more environmentally unstable [ ${ }^{\circ}$, Areas under development: which led to change the features of this site, whether for investment or otherwise [6], and finally the unclaimed areas (virgin) that have not invested or developed yet, whatever type of ownership or tenure (agricultural, residential, or other) [13].

\section{3- Urban planning approaches applied in Egypt and their impact}

The comprehensive urban planning approach (CUP) was the most applied in Egypt since $1950^{\text {th }}$, it provides a physical master plan that includes a study of land uses distribution on an area and focuses on distribution of roads and basic facilities for peoples [7]. It is a central spatial planning carried out by the government or its affiliates, often centrally funded for such plans and implemented as well. This type of planning may be appropriate in planning the new cities and in some planned stable cities (socially and economically), considering the results of studies of environmental, social, and economic dimension of the target population in the city [8]. Investors and local community are not involved in making decisions or contributing to development, especially at planning stage, but they sometimes participate in implementation. The rigidity and centrality of (CUP) and the lack of participation of private and individual beneficiaries caused a failure to apply plans to many cities, especially the existing ones, in which citizens and investors resorted to breaking the law and not applying the conditions that do not suitable for them, Which have led to urban deterioration of facilities and the emergence of informal areas or slums, especially on the outskirts of planned urban areas and areas with law prices such as agricultural land, (Egypt has lost since $1950^{\text {th }}$ more than 2 million acres of best farmland in Delta) [9].

It is worth mentioning that the encroachment on the desert lands and their occupation in an informal way was much less than on agricultural land due to the high costs of development and because of the control of land by some the state institutions as the armed forces [9]. (CUP) did not have the appropriate tools to deal with emergence of informal areas in Egyptian cities, sometimes it represents a part of the problem 
because its lack of flexibility and missing of public participation in decision-making. With the existence of violations and rejection of (CUP), the Egyptian state need to apply an approach that reinforce participation with the private sector and civil society to achieve the urban objectives, especially in existing cities.

Strategic urban planning approach (SUP) was implemented in Egypt in 2008 to give the society a big role in planning and implementation [10]. with the adoption of the implementing regulations of Law 119 (the Unified Building Law) [1], (SUP) was applied in two phases [11]:

The first stage: aims to produce strategic plan (SP) including set of actions and projects for the development of the region through four steps, begin with the basic studies and the collection of information for all sectors of the study, and processing them for SWOT analysis to identify the stresses, weakness, opportunities, and threats. In the second step, the indicators are checked and presentation of the results of the first step, explain the vision and goals to the partners to agree on it for the city to help their development, identify the main objectives and projects that achieve the vision, allocating projects in the city. The results of this phase will determine the urban area of the city, including the identification of all projects. These steps will culminate in the third step in which the strategic plan is being done. The fourth step is the task of adopting (SP) by holding a hearing attendance by the representation (SP) to the government, the local civil society. Individuals, investors, and the private sector, as well as representatives of donors or who wish to participate and support from unions and local and international organizations.

The second stage: is the result of legal detailed plans which represent an effective tool for controlling urbanization. It is an important legal document between the local agencies, citizens or investors who wish to participate in the development of land and create buildings. The outputs of (SUP), which are important tools for urbanization, are:

- Strategic Plan and General Strategic Plan (Development Plan)

- General strategic plan for land use, roads, and infra-structure networks plan

- Description cards for the different project

- Development perspective report and finally detailed plans 


\section{4- Strategic planning and its role in solving the problem of unplanned areas.}

(SUP) has many tools to achieve fully planned urban areas for the society by transforming unplanned urban areas to planned, and to provide the areas with service and facilities projects, in addition to the decisions to expand the streets and re-structure to accommodate the traffic and in line with the provisions of the law. Theoretically, by SWOT tool (SUP) can define the weaknesses and their effects on society, as well as to identify the threats from external influences, whether environmental or legal, or from any human factors, available through the regional and national framework. Also exploring the Vision/ identify goals/ projects with partners, which make the concept of strategic planning, development plan, and proposed projects which can be applied using the strengths and opportunities, prevent threats and weaknesses to solve Problems of the city including unplanned areas. At first, Egypt applied (SUP) to 40 cities in 2007, followed by 29 cities in 2009, then the rest of the existing cities and many new cities, representing the 10th of Ramadan, the 6th of October, and New Cairo, some of which were in partnership between local and foreign consulting offices. It was distributed among the regions of Egypt, 5 cities were in the Greater Cairo Region, 5 in the Alexandria, 9 in the Delta, 8 in the Ismailia, 5 in the northern and central Upper Egypt, and 7 in the southern Upper Egypt.

By listing the 40 cities for which strategic plans were made in 2007 and following up on what happened to them, it was found that all these cities exceeded their planning period to between 4 to 10 times of planned period (6 months), two cities (SP) was approved only in 2009 and the rest between 2010 to 2015, which is about 8 years passed without the adoption and activation of (SP). Some of them were not finally approved (2 cities), and it is also worth noting that the detailed planning stage was not implemented in most of these cities, while the detailed plan was prepared for some of them and was approved in 2020 and 2021, that is, about 13 years after the beginning of the study. With the delay in the (SP) adoption, the features of most of these cities have changed, their mass area has increased, their problems have also increased. Thus, the strategic plan has become unsuitable for the city with these problems and new existing conditions. In one of the studies in this field, a research questionnaire was presented to many 
consultants and planners, it was found that there is no strong impact of the (SUP) on cities, and that there are many negatives and problems encountered in its application, the most important of which are:

- Problems related to the organizational climate: they are related to the centralization system in decision-making, which affects the accreditation periods and makes them longer periods than what is codified, in addition to the weakness of the material and technical capabilities of the auxiliary devices.

- Problems related to the presence of overlap between the authorities and the lack of clarity in the relationship between them.

- the absence of a unified database at the republic level in official information centers in addition to the failure to equip local units at the city level with human and material capabilities that affect the application of the curriculum due to its need for unified and updated information.

- Problems related to the current societal culture: which one of the most obstacles that faced the application of the strategic planning approach regarding the role of civil society, and it is generally related to the unwillingness of civil society to participate in such projects or how to express their opinions.

- Problems related to the preference of developers and some individual investors in the private sector for personal interest rather than the public welfare.

- Problems related to land ownership, as private property is not authorized by low to make any use of it without the consent of its owner.

The study of the 40 cities concluded that the plans that followed (SUP) did not have any role to prevent the spread of informal urban development, and slums increased and many of new informal or slums areas are appeared, and their problems increased and the negative effects of these areas on the population increased.

\section{5- $\quad$ Case Study}

Shubra El-Kheima is an industrial city in Cairo region with an area 6563 fed accommodate about 1.2 million Inhabitants (at 2017), and it 
is one of the cities that apply (SUP), starting in 2012, in agreement between the authority and the Benha University Studies Center. One of the most important goals of its planning was to address the 19 slums areas at the 2 districts (4 at west district, 15 at east districts) in which more than 780 thousand people live and representing more than $27 \%$ of the area (1810 fed.) and with high population densities. Also, the (SUP) aims to solve the dangerous 13 areas problems (under high voltage wires) clarified at table (1) and figure (1).

Table (1): dangerous settlements in Shubhra Alkhema

\begin{tabular}{|c|c|c|c|c|c|}
\hline $\begin{array}{l}\text { No. of } \\
\text { Units } \\
\text { عدد الوحدات }\end{array}$ & $\begin{array}{l}\text { Area } \\
\text { (Fed.) }\end{array}$ & $\begin{array}{r}\text { Ownership } \\
\text { الملكية }\end{array}$ & $\begin{array}{l}\text { Dangerous } \\
\text { level } \\
\qquad \begin{array}{l}\text { الخطورة } \\
\text { الخطوة }\end{array}\end{array}$ & $\begin{array}{l}\text { Zone Name } \\
\text { اسم المنطقة }\end{array}$ & \\
\hline$r \varepsilon$. & $\varepsilon$ & Privat & r & البلاستيك Plastic club & 1 \\
\hline rYo & r, Yo & Privat & $r$ & 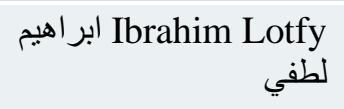 & $r$ \\
\hline rVI & $\varepsilon$, or & Privat & $r$ & Sleem عزبة سليم & $r$ \\
\hline$\varepsilon r q$ & V,r & Privat & r & عزبة الصعايدة Saayda & $\varepsilon$ \\
\hline $19 \varepsilon$ & $r, r$ & Privat & $r$ & Salam city مدينة السلام & 0 \\
\hline rq9 & $7,7 \leq$ & Privat & $r$ & Alfath الفتح & 7 \\
\hline rIT & $r, 0 \leqslant$ & Privat & r & Alvilla & v \\
\hline . & 7 & Privat & $r$ & Bahteem بهنيم & $\Lambda$ \\
\hline$T \leq V$ & $1 \cdot, \times 9$ & Privat & $r$ & المرجوشي عزبة & 9 \\
\hline 114 & $r, 1$ & Privat & $r$ & $\begin{array}{r}\text { مساكن إسكو Esko } \\
\text { Housing }\end{array}$ & 1. \\
\hline Yイ & $\Gamma, T \varepsilon$ & Privat & $r$ & Arab عزبة العرب & 11 \\
\hline$\wedge$ & $\cdot, 1$. & Public & r & $\begin{array}{l}\text { Ezbat Rushdy } \\
\text { مناطق عزبة رشدي (ب) }\end{array}$ & Ir \\
\hline rT & $1, \varepsilon$ & Public & r & Albakry عشش البكري & ir \\
\hline
\end{tabular}




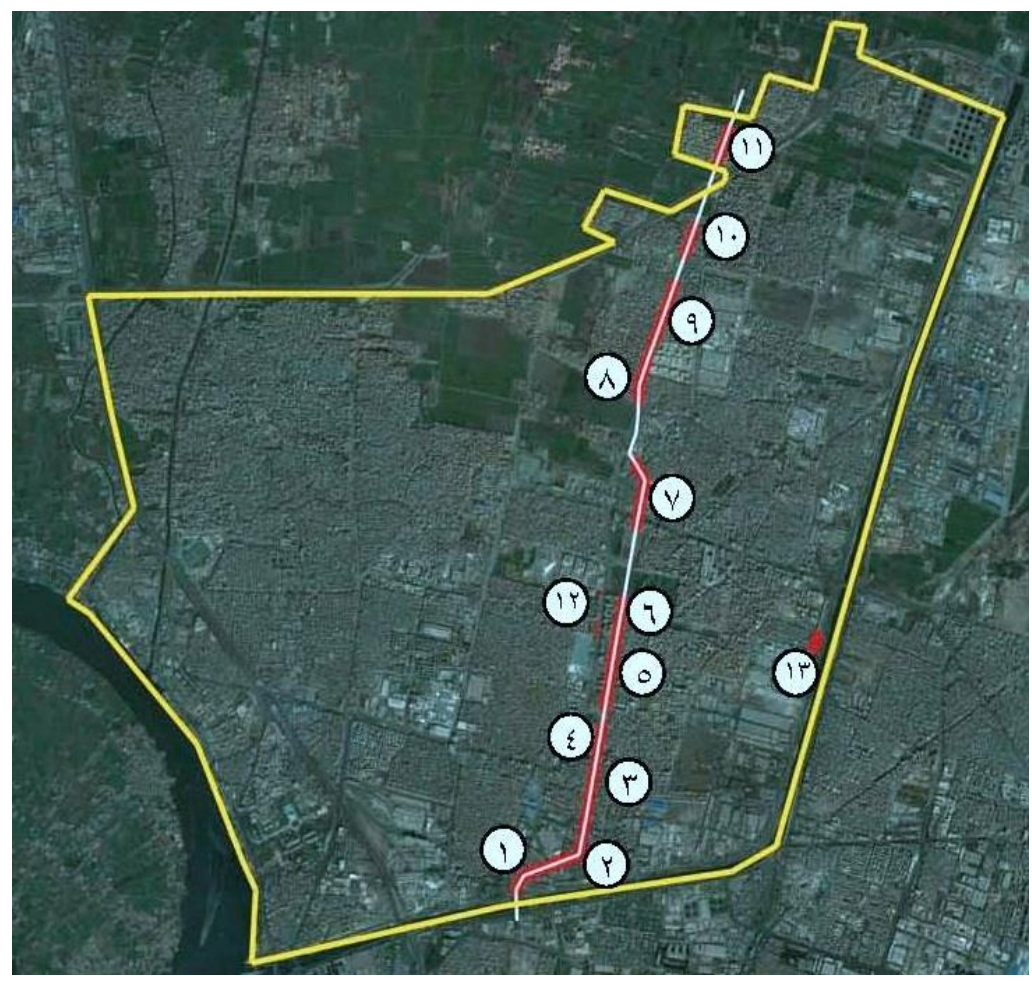

Figure (1): Shubra al-Khaymah 13 Dangerous areas.

There was another study for the treatment of slums carried out by the consultant office at Helwan University, which was adopted in 2013 during the period when the studies of the strategic plan for the city were still being implemented. Also, some detailed areas were adopted during this period, such as the Esco area, north-east of the city.

It is worth noting that there are 5 other detailed plans attached to a report that was approved (without approving the five schemes), and despite that, they have been implemented since 2005, and they have continued to be implemented despite the civil society's refusal to implement them due to the presence of uses that are not commensurate with their desires and capabilities (relying on its right to be Use on his land with his consent in accordance with Law 119), in addition to the presence of problems in understanding some technical terms such as the concept of (public services). The (SP) was prepared and approved in 2020, eight years after the beginning of the study. The most important urban goals were to solve the problems of slums, develop 
them and raise the efficiency of their vital networks and basic services. In this regard, the following projects were proposed:

- Establishing 75515 new housing units (until the target year 2032).

- Encouraging the occupancy of vacant units, which number up to 95,759 units.

- Replacement and renewal of 3,458 damaged housing units in replanning areas.

- Packing the slums unplanned areas (19) with 3,316 housing units.

- Improve the urban conditions of existing housing.

- Transfer of highly polluting industrial uses out of the city.

- Establishment of a proposed regional recreational area.

- Developing the existing educational services, raising their efficiency, and intensifying the number of classes in them, if possible, vertically, or horizontally. The total required is to add 55 primary schools, 12 preparatory schools, 5 general secondary schools, and 4 vocational training centers.

- Establishing 10 general hospitals, 4 specialized hospitals, 53 health units and offices, in addition to 24 ambulance centers.

- Social and Cultural Services, Establishment 11 social affairs offices, 3 social clubs, 6 culture palaces, 16 public libraries and 22 children's libraries.

- Services, of

- Sports services: Establishment of 3 youth centers.

- Security Services: to provide land for the establishment of 4 police stations and 18 police points, as well as 10 fire stations in addition to 16 fire stations.

- Communication services (post offices) Providing 7 post offices.

During the preparation of the strategic plan study, which began shortly after the January 25 revolution (which represent the period of urban chaos), there was a great urban activity, whether with build new floors on existing buildings, or new construction in vacant lands (which reached in 2020 the equivalent of $15 \%$ of the existing construction), most of which are residential towers that sometimes exceed 12 floors on narrow streets, (their widths sometimes range from 6 to 8 meters). 

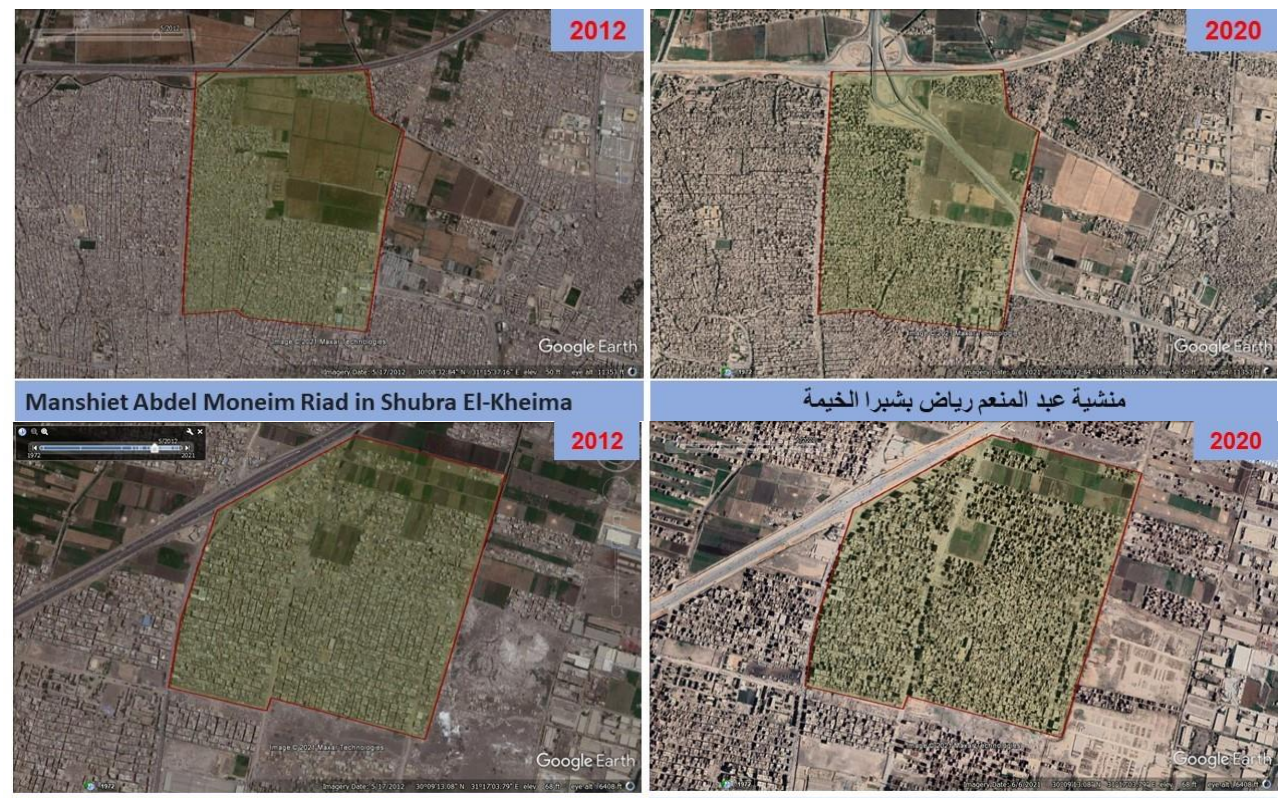

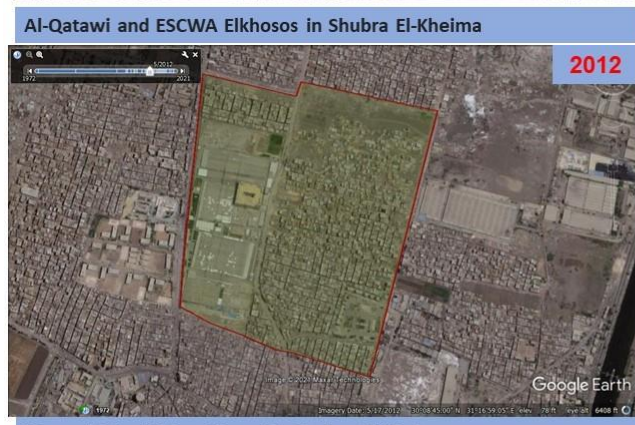

Mostorid And Ezbat Alward in Shubra El-Kheima

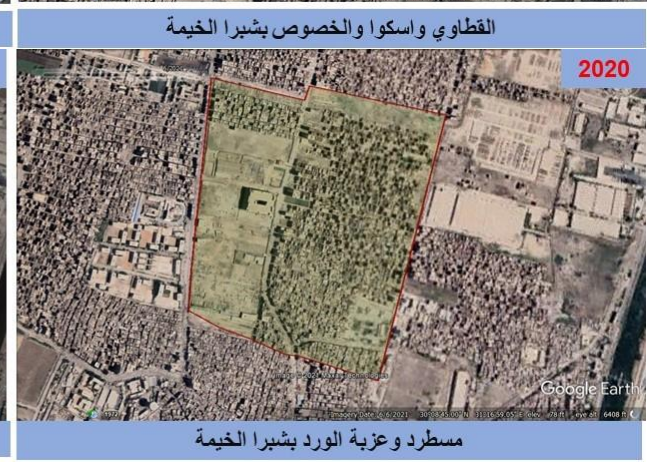

Figure (2): Changes that occurred in 3 slums area in Shubra al-Khaymah between 2012 until the date of its adoption 2020

Most of these constructions did not have any licenses issued by the districts of the city (Less than $4 \%$ from total Buildings), in addition to the establishment of residential buildings by the armed forces and the governorate east of the Ismailia Canal for slum dwellers. The roads and bridges also made a pivotal road linking Ain Shams, El Mataria and El Masala with the ring road to occupy the reclamation lands in which many basic and regional services were proposed to be settled.

Therefore, the proposals to add the necessary services to the city were impractical because most of the vacant lands were lost due to their occupancy in residential buildings, while the population numbers increased, and the number of housing units increased to the degree that 
it caused a collapse in the facilities in the northern extensions such as the Umm Bayoumi area and Al-Manshiyya. Also, services became insufficient in those areas and others, such as Manshiet al-Bakry, Ard al-Umda and West of Esco Neibourhood.

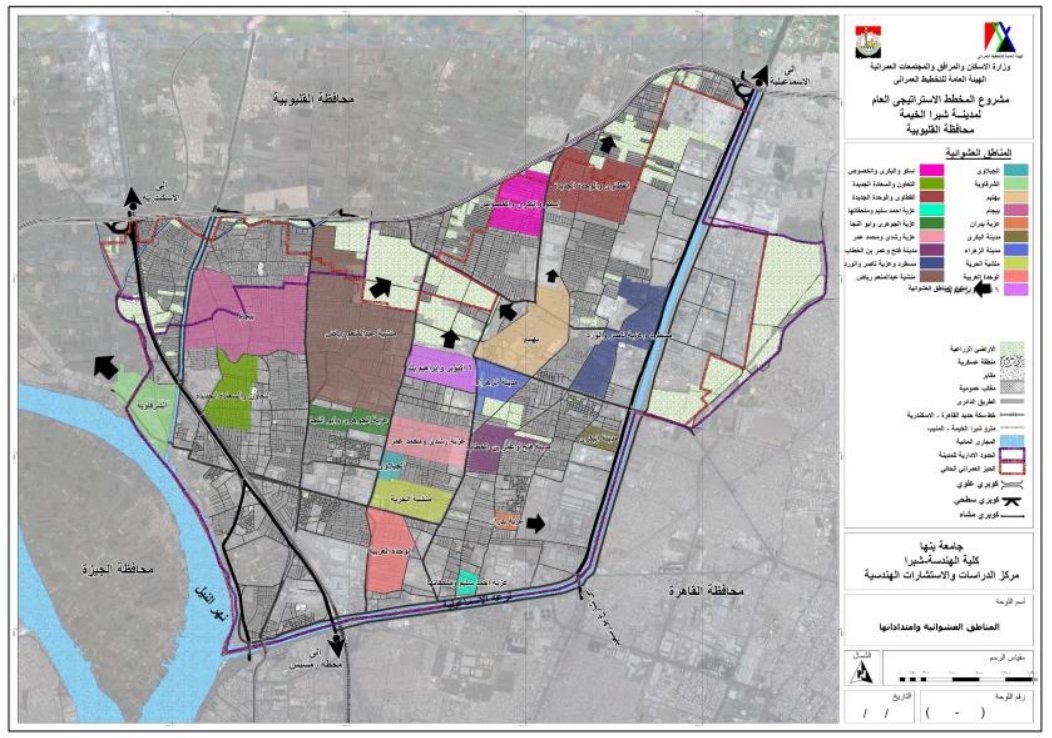

Figure (3): Shubra al-Khaymah 19 slums areas.

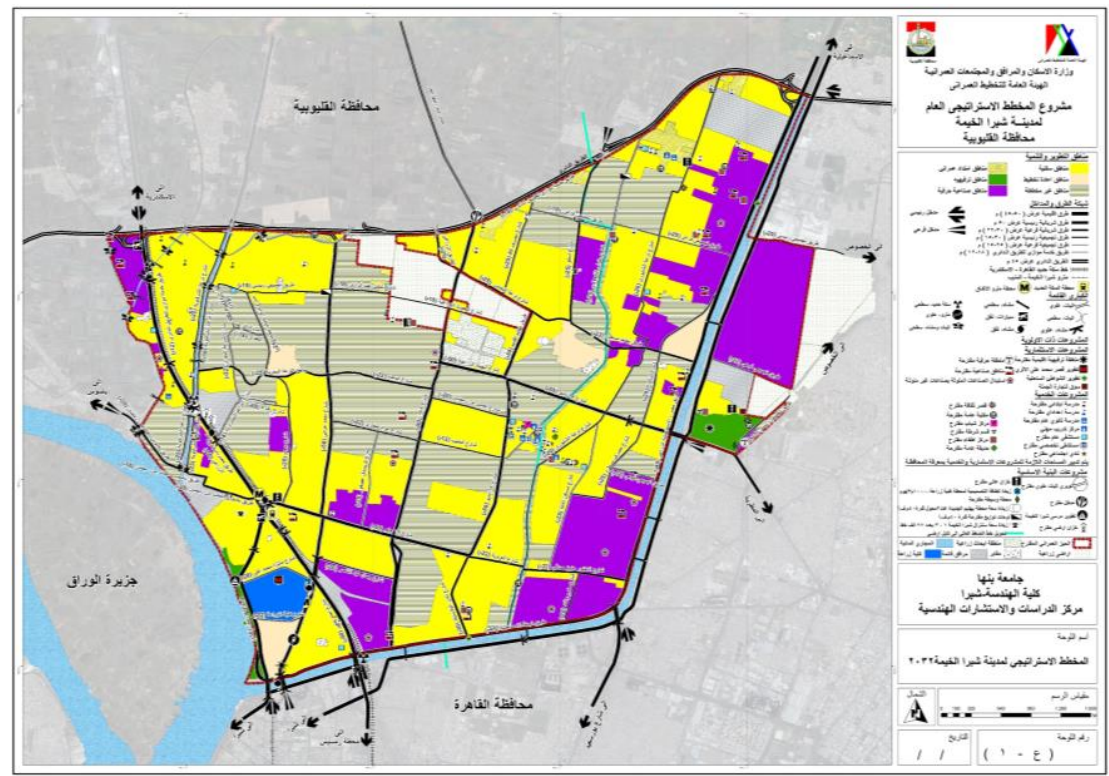

Figure (4) Shubra al-Khaymah (SUP). 
What happened in Shubra al-Khaymah during the study was almost repeated in most of the existing cities, whether the delay in adopting the plans, or the inability of the consultant to distribute the necessary uses to serve the population because shortage of lands allocated for this and far from the ownership of individuals, or the behavior of citizens and individuals to give preference to the private interest over the public well fare, all of this confirms the negative application of (SUP) with its recent tools to the existing cities, and it is necessary to make essential additions and modifications to maximize the benefit from it.

\section{6- The most important problems facing the strategic planning process in Egypt}

Through the previous theoretical study and the case study of Shubra El-Kheima, the location of the scheme and Planned cities which followed (SUP) are rarely show positive impact with (SUP). Most of the existing city's cant apply its (SP). There are many problems facing (SUP) implementation in Egypt, here is some of these problems: -

- Inappropriate selection of development partners because most of them need prior training to participate in such tasks and activities, and some participants are interested in his own interest not on public interest

- Problems due to some of provisions of the law, including the signing of uses on land, where the consultant is prohibited to use any private land for any project without the consent of the owner, making it difficult to provide land projects especially non-residential ones.

- The weakness of the state resources to implement various projects, especially utilities and public services, and the unwillingness of owners of private land to participate in the land of many nonresidential projects on their land.

- Problems caused by an error in compiling information on urbanization, population, environment, and services, and sometimes the inability of the Consultative Group to manage the planning process. 
- The mistrust between the population and state institutions, especially in the field of development.

- Some official statements are illogical and need to be checked and reviewed by other sources, formal or informal, such as the preparation of the population, the borders of the Urban agglomeration, services, and efficiency... etc.

- Sometimes (SP) is not clear to many officials when applied and needs further clarification. It also needs to adopt (SP) for land use with it to clarify the general guiding concepts and facilitate the detailed plans.

Although the strategic plan represents a guiding legal paper to address the urban issues of cities and propose developmental and service projects to provide a suitable environment in all Egyptian citizens in cities (249 cities) and urban areas, the implementation of these schemes were not only in limited ranges and in a few Egyptian cities, as in some cities of Qaliobia and Arish in North Sinai, where detailed plans have been based on the recommendations and studies of (SP) was partially Implemented, for example (1000 lots- project of Build your house). While most of the (SPs) for most Egyptian cities have not been implemented. And because the disadvantages of the (SUP) which weaken its ability to achieve its objectives in general, and (SP) did not lead to sustainable development through the implementation of the proposed projects or help to turn unplanned areas into planned. It was not only the negatives of (SP), but the delay in issuing it for periods of up to five years because of its dependence on various Egyptian bodies and institutions such as the Ministry of Agriculture and Local Affairs and the Committee of Partners and Defense. There are also reasons to resist those who have a private interest to implement the development projects, especially with the right to choose the type of projects that can be located on their own land.

for supporting (SP) to make applicable urban development plan, Rabid planning (RP) was carried out by the General planning organization (GOPP) in cooperation with the German Ministry and applied to some areas in the province of Assiut, using direct intervention to solve the problems of urban and rural areas, considering the application of the regulations and requirements stipulated by the (SP) in the presence of law and 119 requirements and some quarters [16]. (RP) addresses and 
treats the delay in the adoption and issuance of (SP) and is more clear and closer to addressing the urgent problems of the fast-growing city and was the beginning of implementation 2014 and has not shown any positive or negative results yet.

Recently, to make (SUP) (2017-2020) the state make some modification in planning approach and planning types as make the (SUP) only for the upper admirative levels (Government, Region and regional centers in governorates) and they enforce new kind of planning called Urban development plan (UDP) for the city and rural urban communities, the plan that shows the future needs of urban expansion and the economic, social, environmental and urban development projects and plans necessary to achieve sustainable development at the local level within the framework of the future vision of the governorate or Administrative center plan that includes the city or the rural urban community [18]. One of the most important elements that can be achieved by (UDP) is the ability of dealing with unplanned zones as urban upgrading zones which can be upgraded alone or with other zones as new extensions and valuable areas [18].

\section{7- Proposed tools to transform unplanned areas into planned}

Two groups of tools were proposed for reinforcing implementation of (SP) on Egyptian cities specially the existing cities.

- First: added tools and minor amendments on (SUP).

- The presence of trustworthy officials, which is the spark of the start of the draft scheme, the specifications for the development partners selection include the strength of influence, commitment, honesty, integrity, the abundance of supporters, flexibility in the debate, their ability to analyze and effective participation to show opinion to His supporters.

- Training courses for the participants and introducing them to the importance of (SP), and what are the objectives of their participation with the team and clarify the concept of partnership and the role of each member in the development and exploring of strategic planning and localization of projects, and the importance of delivery of the needs and wishes and opinion of their representatives to the consultant, and to deliver and convinced them with decisions. This 
is in addition to consolidating the spirit of cooperation with the team in information Gathering and how to express opinion. The training course also contributes to the consolidation of the principle of the interest of the city and the rejection of any special interest at the expense of the public interest.

- Selecting development partners to be qualified for discussion and opinion (e.g., lawyers), For example, an economic expert representing landlords, investors, demographic expert, or urban planners as a partner responsible for the citizens. There is a legal expert on the local community and a development expert on donors and non- Consultant and officials of the city council and the county.

- The early activation of the role of some institutions and ministries of the state such as agriculture, archeology, state of land use association, roads and bridges and defense, in the presence of the consultation meetings of the city from the beginning, provided that the participants in the adoption of the urban cardoon committee of the estate, it must also find a way to speed up the adoption of approvals from some bodies such as the Armed Forces Operations Commission.

- The approved (SP), which will represent the legal framework, should be as close as possible to the land uses plan, up to the target year, development conditions for areas and buildings must be accurately defined, and the definitions and developmental and land use terms must be easily understood and not ambiguous.

These and other new tools will achieve rapid and fair development in all regions. These treatments and tools will deal with each of the six types described above for how planned and unplanned areas compete for land occupation to help strengthen and strengthen planned areas and reduce opportunities. The seizure of unplanned areas on land, these tools are:

\section{- Second: Additional Tools to applied with (SUP) tasks.}

- Providing a technical support team to evaluate (SP) of the city council or planning department in the governorate, they work to cooperate with consultant and planning department technical team and the city (urban planners) As detailed by law 119. 
- Training tasks on land management and detailed planning for municipality technical planning department and the city council as well as the housing administration. The training course can be carried out practically through their cooperation in preparing the outline of the pilot project on selected areas of the city which contains most of the issues and problems common to the city.

- It may take advantage of Appling the concept of rapid planning and its application to the urban areas of urgent need, the selection of those areas through the consultant authorized must be agreed by the (GOPP) in cooperation with the province or the city council, during the first phase of planning process.

- Drawing urban map according to their planning situation for determining the planned $\backslash$ unplanned urban areas at the city level, this begins with studying its growing development, then studying areas characteristics and emergence reasons, and use the tool of SWOT analysis to determine the solution and haw to deal with.

- It may also use Urban and territorial planning which primarily aims to realize adequate standards of living and working conditions for all segments of current and future societies, ensure equitable distribution of the costs, opportunities and benefits of urban development and particularly promote social inclusion and cohesion. It's a precondition for a better quality of life and successful globalization processes that respect cultural heritages and cultural diversity. For the recognition of the distinct needs of various groups. It's also providing a spatial framework to protect and manage the natural and built environment of cities and territories, including their biodiversity, land, and natural resources, and to ensure integrated and sustainable development [16].

- Applying (UDP) will give some solution for unplanned areas specially if we give the planning consultant more power to manage and control land use of the land, that will be strong tool to solve unplanned areas problems.

- Using the (planned unplanned analytical tool) as it will be applied later in case study (GCR)

These additions and modifications will help strengthen the role of the planner and local authorities in controlling urbanization, increasing the 
chance of controlling the planned areas and reducing the chances of competition for unplanned areas of land occupation.

\section{8- Conclusion and results}

- most of the unplanned areas appeared, strongly emerged despite the existence (SUP) tools of strict and clear but were rejected by society and rebelled against them for not involved in the planning process (they considered that the planning does not represent them and does not suitable).

- Among the participatory groups, the planning lacks justice and equity and the problem of some of the rebellion against this planning.

- Many involved civil society members in making decisions for (SP) did not have enough experience to clarify their demands, and did not have clear concepts of how to reach or explore (SP), it is necessary to prepare training courses in decision-making and planning process for partners and for local and technical professionals from the city and the governorate, that will result in a developmental plan that push the city for the better,

- Partners should have some experience and technical awareness in sectorial fields as: urban, social, environmental, and economic, which will facilitate the planning process in consultation sessions of the city, and these technical partners can have an effective role in communicating their commissioner's requests and convince them of the decisions reached.

- Accelerate the work of the strategic plan with no loss or deficiency or weakness in any of its components and studies will have a positive impact on the city, and in the case of delayed adoption will be necessary to apply a rapid planning approach to one or some areas to prevent the random and informal, especially areas of the border or adjacent areas. 


\section{9- References}

[1]. Ministry of Construction and New Urban Communities - 2008 - Issue 2011Unified Building Law 119 and its Executive Regulations (In Arabic language).

[2]. The Institute for Local Government- Understanding the Basics of LAND USE AND PLANNING: Glossary of Land Use and Planning Terms- 2010 Sacramento, CA 95814.

[3]. https://www.ldoceonline.com/dictionary/developed-land - Accessed 2018

[4]. Zain al-Abidin Ali Safar - Measuring the underdevelopment of urban areas and methods of evaluating it - Journal of Kirkuk University / for Human Studies Volume VII / Issue 2 / Seventh Year 2012

[5]. Jelena Živanović Miljković1, Tijana Crnčević, Igor Marić, LAND USE PLANNING- FOR SUSTAINABLE DEVELOPMENT OF PERI-URBAN ZONES - SPATIUM International Review UDC 711.4-13/.14(497.11); No. 28, December 2012.

[6]. https://www.lawinsider.com/dictionary/land-under-development- accessed 2020

[7]. Ahmed Khaled Allam and others - Regional Planning - Anglo-Egyptian Library - 1990 (In Arabic language).

[8]. Richard Shearmur, McGill University, what is an urban Structure? The challenges of foreseeing 21st Century Patterns of the Urban Economy, 2013 from Web site https://www.researchgate.net/publication/297225871 What is an urban Str ucture The challenges of foreseeing 21st Century Patterns of the Urban Economy.

[9]. 8- The Egyptian Council of Ministers - Information and Decision Support Center - Egypt Vision 2030 - 2014 (In Arabic language).

[10]. 9- King Saud University - 1434 AH - Traditional and Strategic Urban Planning.

[11]. 10- The General Authority for Urban Planning GOPP - Work guide for preparing the strategic plan - 2014-2015 (In Arabic language).

[12]. 11- Executive Regulations of the System of Expropriation of Real Estate for the Public Benefit and Temporary Seizure of Real Estate, Saudi Council of Ministers - 1437 AH - Resolution (54) (In Arabic language).

[13]. 12- UNESCO - World Heritage Center - Urban Revival Project for Historic Cairo - Management of World Heritage Sites in the Republic of Egypt - 2012 (In Arabic language).

[14]. David Sims -Contribution by Marion Sejoume and Monika El Shorbagi- The case of Cairo, Egypt - Global Report on Human Settlements - 2003.

[15]. United Nations Human Settlements Programme- International Guidelines on Urban and Territorial Planning- UN-Habitat- Nairobi - 2015.

[16]. Staroměstské náměstí, Praha, Institute for Spatial Development, Jakubské náměstí Brno- PRINCIPLES AND RULES OF URBAN PLANNING COMPOSITION IN EXAMPLES- 2016. 
[17]. Environmental and Resource Management for Highly Dynamic Metropolises2016 Rapid Planning- Sustainable Infrastructure,

[18]. Ministry of Construction and New Urban Communities - Amendments to the Unified Building Law 119 and its Executive Regulations - 2017-2020. https://www.almasryalyoum.com/news/details/1219117 accessed Mars 2021(In Arabic language).

[19]. the consulting office at Helwan University in cooperation with the city council and the GOPP - 2007- The project of inventorying and packing slums on the outskirts of Greater Cairo (Shubra Al-Khaimah city) (In Arabic language).

[20]. Qalyubia Governorate - Studies Center, Benha University in cooperation with the GOPP - 2012 / 2020- The strategic plan project for the city of Shubra AlKhaimah (In Arabic language).

[21]. Slum Development Fund (guaranteeing safe residential areas), Presidency of the Council of Ministers- 2013- Project of inventory and classification of unsafe areas in Qalyubia Governorate.

[22]. SolimanM. Ahmed,2018- Strategic planning of the Egyptian city between theory and practice- Journal of Engineering Sciences (JES) Faculty of Engineering Assiut University - Volume $\leqslant$ ฯ, Issue $\varepsilon$-JUL 2018 (In Arabic language). 


\section{دور التخطيط الاستراتيبي في التنافس العمراني المكاني ما بين المناطق المخططة والمناطق غير المخططة داخل المناطق الحضرية من اقليم القاهرة الكبري.}

الاستعمالات تتنافس وتتصار ع فيما بينها لكي تسيطر على مساحات الار اضي المختلفة داخل

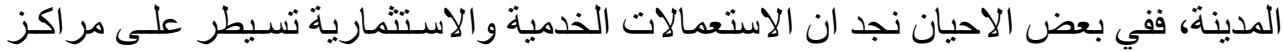

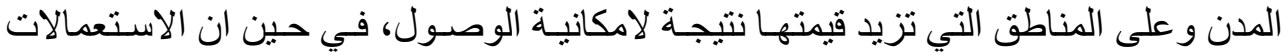

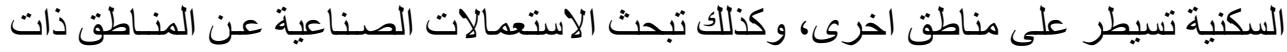

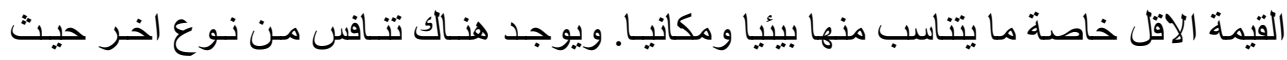

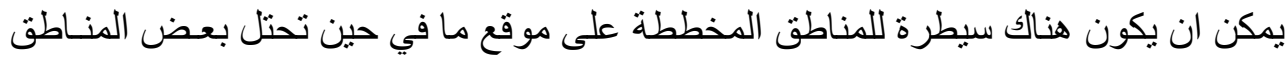

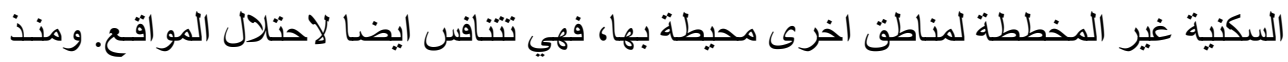

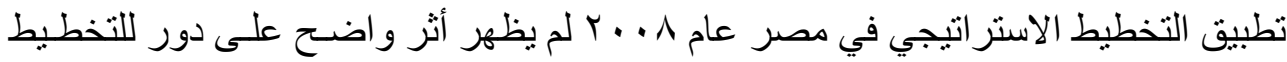

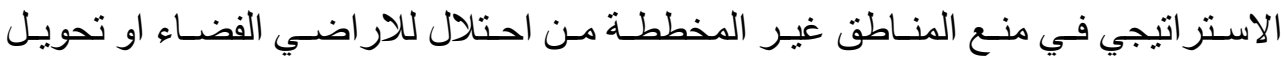

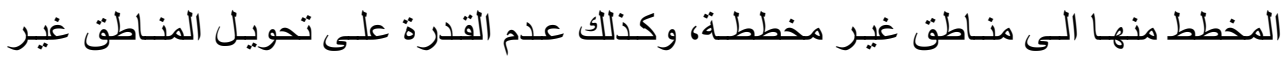
المخططة الى مخططة لعدم وجود امكانية للضغط على اصحاب الملكيات الخاصة.

الهـف من البحث: يهدف البحث إلى إنشاء خريطة توضـح التفاعل بين المنـاطق الحضـرية

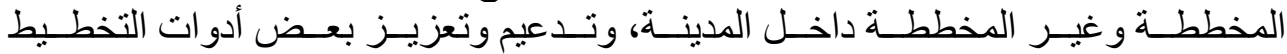

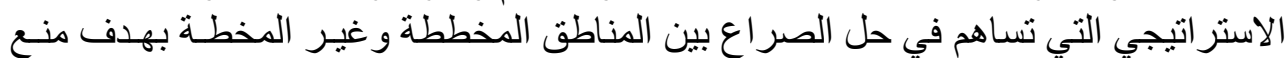

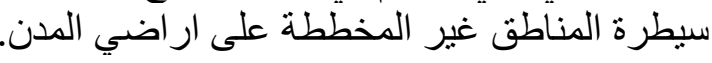

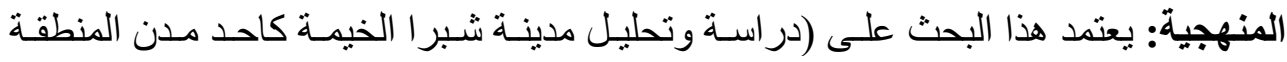
الحضرية لمنطقة القاهرة الكبرى - مصر ) كدر اسة حالة لنطبيق النهئ المنهجية.

كلمـات مفتاحيـة: مـنهج التخطـيط الاسـتر اتيجي- المنـاطق المخطـطـو الغيـر مخططـة الاستعمالات المتنافسة. 